\title{
Cold Adapted Variants of Iníluenza A
}

\section{Comparison of the Genetic and Biological Properties of $t s$ Mutants and Recombinants of the Cold Adapted A/AA/6/60 Strain}

By

\author{
S. B. Spring 1 , H. F. Maassab $2 *$, A. P. Kendal ${ }^{3}$, \\ B. R. Murphy ${ }^{1}$, and R. M. Chanock ${ }^{1}$ \\ 1 Laboratory of Infectious Diseases, \\ National Institute of Allergy and Infectious Diseases, National Institutes of Health, \\ Bethesda, Maryland, U.S.A. \\ 2 Department of Epidemiology, School of Public Health, University of Michigan, \\ Ann Arbor, Michigan, U.S.A. \\ 3 Respiratory Virology Branch, Bureau of Laboratories, Center for Disease Control, \\ Atlanta, Georgia, U.S.A.
}

Accepted June 15, 1977

\section{Summary}

The genetic and biological properties of 13 recombinant influenza $A$ clones derived at $25^{\circ} \mathrm{C}$ from the $\mathrm{A} / \mathrm{AA} / 6 / 60$-cold variant (by crosses with 4 different wild type strains) were compared with a set of 5 - FU induced ts-mutants. The 5-FU mutants had previously been placed into 7 complementation-recombination groups; the $\mathrm{A} / \mathrm{AA} / 6 / 60$-cold parent (PI-7) and the 12 cold recombinant clones which were $t s$ were shown to share a lesion with only one of these groups. The parental strain and 5 recombinant clones were evaluated for replication in the lungs and nasal turbinates of hamsters. Fach virus appeared to be attenuated; genetic stability correlated with the level of viral replication in the hamster lung, i.e., viruses which grew best showed a tendency to revert to the $t s^{+}$phenotype. Characterization of the $t s^{t}$ revertants for the presence of the cold adaptation property revealed that these viruses exhibited a spectrum of cold adaptation properties. Two viruses, PI-7 (the parental cold variant) and the CR 6 recombinant (A/Queensland/6/72) did not revert in either the lungs or nasal turbinates of hamsters.

\section{Introduction}

Cold adapted variants of influenza A virus have been suggested as candidate live virus vaccine strains or as donors of attenuation factors to new antigenic

* Supported in part by the Office of the U.S. Army Medical Research and Development Command, Department of the Army, under Research Contract DADA 17-73C-3060. 
variants. These viruses have been shown to be attenuated with respect to replication in man, mice, and ferrets $(1-3,7-10,12,22)$. A potential advantage of cold variants as donors of attenuation genes is the association of an in vitro marker with this property. Thus, variants and recombinants can be assessed for the cold adaptation (ca) property in tissue culture prior to evaluation in man. In addition many of the cold variants and recombinants are temperature sensitive in chick kidney and rhesus monkey kidney tissue culture $(7-10,13,23,26)$. The ts property provides a second in vitro marker, and allows genetic analysis to determine the nature of the ts lesion(s) in these viruses. As probes for $t s$ lesions we have used $9 \mathrm{ts}$ mutants of influenza A virus derived by 5 fluorouracil ( $5 \mathrm{FU}$ ) mutagenesis. The 5 FU mutants have been placed into 7 complementation-recombination groups (25) on the basis of a complementation-recombination assay carried out directly on the tissue culture monlayer.

The updating of $t s$ vaccine strains has been demonstrated in studies in which recombinants have been prepared using a well characterized $t s$ strain as a donor of attenuating genes to antigenically different wild type $(w t)$ strains $(15,19,21)$. These recombinants were evaluated for several properties: i) genetic analysis was carried out by the complementation-recombination assay to determine whether the recombinant viruses had each of the lesions present in the ts parent and only these lesions, ii) attenuation was evaluated by comparing the efficiency of plaque formation at $33^{\circ}, 37^{\circ}, 38^{\circ}$ and $39^{\circ} \mathrm{C}$ and by studying restriction of growth in the lungs and nasal turbinates of infected hamsters, and iii) genetic stability was evaluated by studying the frequency of isolation of $t s^{+}$revertants from the lungs and nasal turbinates of infected animals. The present studies used the A/AA/6/60 cold variant as a donor of attenuating genes to 4 different wt strains. The 13 recombinant clones derived at $25^{\circ} \mathrm{C}$ were evaluated by the above 3 criteria.

\title{
Materials and Methods
}

\author{
Viruses \\ ts Mutants
}

The production and eharacterization of the $t s$ mutants and $t s$ recombinants used as prototypes for each of the complementation groups has been detailed previously $(17,19,24,25)$. The history and phenotype of the viruses used in the hamster studies are summarized in Table 1.

\section{Cold-Adapted Variants and Recombinants}

The derivation of prototype cold-adapted A/Ann Arbor/6/60 ( $\mathrm{H} 2 \mathrm{~N} 2$ ) virus by successive multiple passages in chick kidney (CK) tissue at progressively lower temperatures has been described (7). This variant had been cloned by 7 successive plaque-toplaque passages in CK cells at $25^{\circ} \mathrm{C}$ before preparing working seed stocks by passage in eggs. Four recombination experiments were done to transfer cold-adaptation genes to wild-type H3N2 strains A/Queensland/6/72, A/Ann Arbor/9/73, A/Dunedin/4/73 and $A / S c o t l a n d / 840 / 74$, and the recombinants derived were designated respectively CR 6, CR 12, CR 13 and CR 18. The method of recombination by mixedly infecting CK cells at $25^{\circ} \mathrm{C}$ with wild-type virus and A/Ann Arbor/6/60 has been previously described $(9,11)$, as has another slight modification of the technique to isolate 10 elones of CR $18(6)$.

\section{Antigenic Analysis}

The identity of the hemagglutinin (HA) in all recombinant cold-adapted viruses was determined initially by $\mathrm{HI}$ testing using ferret sera to the parental wild-type 
$\mathrm{H} 3 \mathrm{~N} 2$ and cold-adapted $\mathrm{H} 2 \mathrm{~N} 2$ viruses. Confirmation of the identity was obtained by using antiserum to appropriate recombinant strains containing $\mathrm{H} 2$ or $\mathrm{H} 3 \mathrm{hem}$ agglutinin and the neuraminidase of A/equine/Prague/1/56 (Neq 1). The identity of the neuraminidase (NA) in recombinants was determined by NI testing using rabbit immune serum to the isolated NA of A/Ann Arbor/6/60 (5) or to a recombinant A/equine/ Prague/1/56 (Heq 1)-Port Chalmers/1/73 (N 2), since all wild-type H $3 \mathrm{~N} 2$ viruses used in this study possessed a neuraminidase antigenically similar to that of the A/Port Chalmers/1/73 (Kendal, unpublished observation).

\section{Growth and Assay of Infectious Virus}

The procedures used to produce virus suspensions and to assay their infectivity have been detailed previously $(14,16)$. Infectivity was titrated by inoculation of serial 10 -fold dilutions of a virus suspension into primary rhesus monkey kidney (RMK) roller tube cultures or 24-well Costar tissue culture plates. After 3-5 days incubation at $33^{\circ}$ or $39^{\circ} \mathrm{C}$ the presence of virus was determined by hemadsorption with 0.1 per cent guinea pig erythrocytes.

Suspensions of ts mutants, cold variants, or cold recombinants were prepared by allantoic inoculation of 10 day old ernbryonated eggs. The allantoic fluid was harvested after 48-72 hours incubation at $33^{\circ} \mathrm{C}$. Embryonated eggs were obtained from either Truslow Farms (Chestertown, Maryland) or SPAFAS Inc, (Storrs, Connecticut).

Plaque assays were performed using RMK monolayers grown on plastic petri dishes. An agar overlay consisting of 0.9 per cent agarose, medium L-15 and antibiotics was used $(14,16)$. In studies performed at restrictive temperatures $\left(37^{\circ}, 38^{\circ}\right.$ and $\left.39^{\circ} \mathrm{C}\right)$ the tissue culture plates were sealed in steel boxes which were placed in a constant temperature circulating water bath (maximum variation $0.05^{\circ} \mathrm{C}$ ). Tissue cultures were purchased from Flow Laboratories, Ine. (Rockville, Maryland).

Studies comparing the efficiency of plating of virus strains and isolates at $25^{\circ}$ and $33^{\circ} \mathrm{C}$ were carried out in $\mathrm{CK}$ cultures. The preparation of these cells from 1 to 4 day old chicks and the assay procedure have been previously described $(7,8)$. The cultures consisted primarily of epithelial cells, but some fibroblasts were also observed.

\section{Complementation-Recombination Assay}

The technique for detection of complementation-recombination on the assay plate has been decribed previously $(14,25)$; it is outlined in the Results section.

\section{Hamster Studies}

Outbred female Syrian hamsters, 4-6 weeks old, were obtained from Lakeview Animal Farms, Inc., (Philadelphia, Pennsylvania). Animals were anesthetized by intraperitoneal administration of pentobarbital, and $0.1 \mathrm{ml}$ of virus suspension was administered intranasally. Each day for 1 to 4 days post-infection. groups of hamsters were anesthetized and their lungs and nasal turbinates removed. The lungs from each animal were mixed with alundum, ground with a mortar and pestle, and suspended in $7.5 \mathrm{ml}$ of Hanks' BSS containing 0.5 per cent gelatin and antibiotics (14). After centrifugation at $1500 \times g$ for 15 minutes at $4^{\circ} \mathrm{C}$, the supernatant was removed and stored frozen at $-70^{\circ} \mathrm{C}$. The turbinates were treated identically except that they were suspended in $4 \mathrm{ml}$ of Hanks' BSS; this procedure resulted in an approximate 10 per cent $w / v$ suspension for the lungs, and 5 per cent $w / v$ for the turbinates.

The viral content of the tissues was determined by titration in RMK roller tube cultures or 24 well Costar tissue culture dishes maintained with a 1:1 mixture of Eagle's medium and medium 199 containing antibiotics. Each 10-fold dilution of the tissue suspension was inoculated into 4 roller-tube cultures, and the presence of virus detected by hemadsorption after 3 days of incubation at $33^{\circ} \mathrm{C}$ (2 cultures) or $39^{\circ} \mathrm{C}$ ( 2 cultures). Viral titers of the tissue suspensions expressed as 50 per cent tissue culture infective doses $\left(\mathrm{TCID}_{50}\right.$ ) at $33^{\circ} \mathrm{C}$ were estimated by the method of KARBir (4). The fluid medium from tissue cultures that had been inoculated with the undiluted tissue suspension and incubated at $33^{\circ} \mathrm{C}$ was saved and designated as the RMK isolate. Virus present in these isolates was subsequently tested for its ability to initiate plaque formation at $33^{\circ}$ or $39^{\circ} \mathrm{C}$. 
Plaques that appeared at $39^{\circ} \mathrm{C}$ were picked and inoculated onto RMK tissue culture. The fluids from these eultures were harvested after 3 days incubation at $33^{\circ} \mathrm{C}$. The RMK suspensions were subsequently used as inocula for 9 day old embryonated eggs. The virus in the allantoic fluid was then characterized for its $t s$ and $c a$ properties in RMK and CK tissue cultures respectively.

\section{Results}

\section{Antigenic Analysis}

Analysis by the HI technique indicated that each of the recombinant viruses had the hemagglutinin derived from the wild type parent (Table 1). Study of the recombinants by the neuraminidase-inhibition technique (Table 2) indicated that the CR6, CR 12 and CR 13 viruses had the neuraminidase characteristic of the wild type parent. Of the 10 clones derived from the A/AA/6/60-cold variant (PI-7) $\mathrm{X}$ Scotland cross, 6 had $\mathrm{N} 2_{60}$ antigen while 4 had $\mathrm{N} 22_{74}$ antigen.

Table 1. History and phenotype of cold adapted variants, cold recombinants and ts recombinant viruses used to infect hamsters

\begin{tabular}{|c|c|c|c|c|}
\hline $\begin{array}{l}\text { Clone } \\
\text { designa- } \\
\text { tion }\end{array}$ & Origin of elonea & $\begin{array}{l}\text { Antigenic } \\
\text { subtype }^{h}\end{array}$ & $\begin{array}{l}\text { Shut } \\
\text { off } \\
\text { temp. }\end{array}$ & $\begin{array}{l}\text { Comple- } \\
\text { menta- } \\
\text { tion } \\
\text { group }\end{array}$ \\
\hline PI-7 & Cold adaptation of wt-A/AA/6/60 & $\mathrm{H} 2_{60} \mathrm{~N} 2_{60}$ & 37 & 1 \\
\hline CR 6 & $\begin{array}{l}\text { Recombination of PI- } 7 \text { with } \\
\text { wt-A/Queensland } / 6 / 72\end{array}$ & $\mathrm{H} 3_{72} \mathrm{~N} 22_{72}$ & 37 & 1 \\
\hline CR 12 & $\begin{array}{l}\text { Recombination of PI- } 7 \text { with } \\
\text { wt-A/AA/9/73 }\end{array}$ & $\mathrm{H} 3{ }_{73} \mathrm{~N} 22_{73}$ & 38 & 1 \\
\hline $\begin{array}{l}\text { CR } 18 \\
\text { Clone } 6 \\
\text { Clone } 7\end{array}$ & $\begin{array}{l}\text { Recombination of PI- } 7 \text { with } \\
\text { wt-A/Scot/840/74 }\end{array}$ & $\mathrm{H} 3_{74} \mathrm{~N} 2_{74}$ & $\begin{array}{l}38 \\
37\end{array}$ & $\begin{array}{l}1 \\
1\end{array}$ \\
\hline$t s-1[\mathrm{E}]$ & $\begin{array}{l}\text { Recombination of } \mathrm{H} 2 \mathrm{~N} 2 \text {-ts } 1 \\
\text { with wt-A/Hong Kong/45/68 }\end{array}$ & $\mathrm{H} 3_{68} \mathrm{~N} 2_{65}$ & 38 & 1,2 \\
\hline$t s-[189]$ & $\begin{array}{l}\text { Recombination of } \mathrm{H} 3 \mathrm{~N} 2-t s-1 \text { [A] } \\
\text { with wt-A/Udorn/307/72 }\end{array}$ & $\mathrm{H} 3{ }_{72} \mathrm{~N} 2_{68}$ & 37 & 1 \\
\hline$t s-[$ clone 13$]$ & $\begin{array}{l}\text { Recombination of wt-A/Udorn/ } \\
307 / 72 \text { and } \mathrm{H} 3 \mathrm{~N} 2-t s-1 \text { [E] }\end{array}$ & $\mathrm{H} 3_{72} \mathrm{~N} 2{ }_{72}$ & 39 & 1 \\
\hline
\end{tabular}

a References: P 17, CR 6, CR 12 $(7,11) ; t s-1$ [E] $(24,25) ; t s-[189](19) ; t s-[$ clone 13$](20)$

b The determination of these characteristics is described in the text

\section{Characterization of Cold Recombinants With Respect to Efficiency of Plaque Formation (EOP)}

None of the wt parental viruses formed plaques at $25^{\circ} \mathrm{C}$ (Table 2). The plaque titer of the $\mathrm{A} / \mathrm{AA} / 6 / 60$ cold variant (PI-7) and the 13 cold recombinants in $\mathrm{CK}$ cells was only slightly reduced at $25^{\circ} \mathrm{C}$ compared to $33^{\circ} \mathrm{C}$. Thus the A/AA/6/60 cold variant (PI-7) and its 13 cold recombinant elones were cold adapted. 
Replicate sets of RMK monolayers were inoculated with serial dilutions of the cold variant or one of the cold recombinants and incubated for 3 days at $37^{\circ}, 38^{\circ}$ or $39^{\circ} \mathrm{C}$ or for 5 days at $33^{\circ} \mathrm{C}$. Table 2 presents the average $\log _{10}$ reduction of titer at each of the 3 restrictive temperatures with respect to titer at the permissive temperature $\left(33^{\circ} \mathrm{C}\right)$. Two to three tests were performed on different lots of RMK cells. The shutoff temperature of each mutant was arbitrarily chosen as the lowest temperature at which there was a 100 fold or greater decrease in titer. The titer of each of the parental viruses was the same at $33^{\circ}, 37^{\circ}, 38^{\circ}$ and $39^{\circ} \mathrm{C}$. Although all 13 recombinant clones were derived from the same cold parent (PI-7) there were 5 clones with a shut-off temperature of $37^{\circ} \mathrm{C}$ and 7 clones with a shut-off temperature of $38^{\circ} \mathrm{C}$. The $\mathrm{A} /$ Dunedin $/ 4 / 73$ recombinant (CR 13) was not temperature sensit:ve; i.e. it was not restrieted in plaque formation at $39^{\circ} \mathrm{C}$ and was therefore not suitable for genetic analysis.

Table 2. Growth of parental strains, cold variant and cold recombinants at permissive and restrictive temperatures

\begin{tabular}{|c|c|c|c|c|c|}
\hline \multirow{2}{*}{$\begin{array}{l}\text { Virus } \\
\text { Parental wt strains }\end{array}$} & \multirow[t]{2}{*}{$\begin{array}{l}\log _{10} \text { reduc- } \\
\text { tion of titer } \\
\text { at } 25^{\circ} \mathrm{C} \text { from } \\
\text { titer observed } \\
\text { at } 33^{\circ} \mathrm{C} \text { in } \mathrm{CK}\end{array}$} & \multicolumn{3}{|c|}{$\begin{array}{l}\log _{10} \text { reduction of titer at } \\
\text { indicated restrictive tem- } \\
\text { perature from titer ob- } \\
\text { served at permissive tem- } \\
\text { perature }\left(33^{\circ} \mathrm{C}\right) \text { in RMK }\end{array}$} & \multirow[t]{2}{*}{$\begin{array}{l}\text { Shut } \\
\text { off } \\
\text { temper- } \\
\text { ature }\end{array}$} \\
\hline & & $37^{\circ} \mathrm{C}$ & $38^{\circ} \mathrm{C}$ & $39^{\circ} \mathrm{C}$ & \\
\hline $\mathrm{A} / \mathrm{AA} / 6 / 60^{\mathrm{b}}$ & $>8.3$ & 0.0 & 0.0 & 0.0 & $>39$ \\
\hline A/Queen/6/72 & $>7.3$ & 0.0 & 0.0 & 0.0 & $>39$ \\
\hline A/AA/9/73 & $>7.0$ & 0.0 & 0,0 & 0.0 & $>39$ \\
\hline A/Dunedin/4/73 & $>6.8$ & 0.0 & 0.0 & 0.0 & $>39$ \\
\hline $\mathrm{A} / \mathrm{S} \cot / 840 / 74$ & $>7.5$ & 0.0 & 0.0 & 0.0 & $>39$ \\
\hline \multicolumn{4}{|l|}{ Parental cold variant } & $>5.9$ & $\leq 37$ \\
\hline \multicolumn{6}{|l|}{ Cold recombinants of PI-7 } \\
\hline CR $6\left(\mathrm{~A} /\right.$ Queen/6/72) ${ }^{\mathrm{c}}$ & 0.1 & 2.3 & $>6.7$ & $>6.7$ & $\leq 37$ \\
\hline CR $12(\mathrm{~A} / \mathrm{AA} / 9 / 73)$ & 0.1 & 0.9 & 4.9 & $>6.3$ & 38 \\
\hline CR 13 (A/Dunedin/4/73) & 0.5 & 0.0 & 0.0 & 0.0 & $>39$ \\
\hline \multicolumn{6}{|l|}{ CR $18(\mathrm{~A} / \mathrm{S} \cot / 840 / 74)$} \\
\hline Clone $1 \mathrm{~N} 2(74)^{\mathrm{d}}$ & 0.4 & 1.5 & $>6.0$ & $>6.0$ & 38 \\
\hline Clone $2 \mathrm{~N} 2(74)$ & 0.3 & 3.7 & $>8.0$ & $>8.0$ & 37 \\
\hline Clone $3 \mathrm{~N} 2(60)$ & 0.5 & 1.4 & $>7.5$ & $>7.5$ & 38 \\
\hline Clone 4 N2 $(60)$ & 0.5 & 3.0 & $>7.0$ & $>7.0$ & 37 \\
\hline Clone $5 \mathrm{~N} 2(60)$ & 0.1 & 1.0 & $>7.3$ & $>7.3$ & 38 \\
\hline Clone $6 \mathrm{~N} 2(74)$ & 0.3 & 0.9 & $>6.2$ & $>6.2$ & 38 \\
\hline Clone $7 \mathrm{N2}(74)$ & 0.7 & $>7.0$ & $>7.0$ & $>7.0$ & $\leq 37$ \\
\hline Clone $8 \times 2(60)$ & 0.5 & 0.8 & $>7.2$ & $>7.2$ & 38 \\
\hline Clone $9 \mathrm{~N} 2(60)$ & 0.0 & $>7.0$ & $>7.0$ & $>7.0$ & $\leq 37$ \\
\hline Clone $10 \mathrm{~N} 2(60)$ & 0.6 & 1.6 & $>6.9$ & $>6.9$ & 38 \\
\hline
\end{tabular}

a Defined as a 100 fold or greater reduction in plaquing efficiency on RMK monolayers

b Data for the A/AA/6/60 and PI-7 viruses are also presented in Paper I of this series (23)

c wt parent

d Neuraminidase subtype 


\section{Genetic Characterization of Cold Adapted Variants}

The PI-7 parent and 12 cold recombinant $t s$ clones were analyzed genetically by the plate complementation-recombination technique. The nine $5 \mathrm{FU}$ mutants previously assigned to 7 complementation groups were used as prototype strams (24). The procedure has been detailed previously $(24,25)$. Briefly, pairs of mutants were mixed and incubated at $4^{\circ} \mathrm{O}$ for 18 hours; serial dilutions of the mixtures were made and inoculated onto RMK cell monolayer cultures which were then incubated at $39^{\circ} \mathrm{C}$. Each of the mutants was also assayed separately by the plaque technique at $33^{\circ} \mathrm{C}$ and $39^{\circ} \mathrm{C}$. The resulting titer at $33^{\circ} \mathrm{C}$ was used to estimate the multiplicity of input (MOI). Few if any plaques developed following incubation of singly infected cultures at $39^{\circ} \mathrm{C}$. In each test wild type influenza A/Hong Kong/ 1968 virus and/or the wt parental strains were assayed at $33^{\circ} \mathrm{C}$ and $39^{\circ} \mathrm{C}$ and the titers were always approximately equal at the 2 temperatures. Complementation was assumed to occur in dually infected cells incubated at $39^{\circ} \mathrm{C}$ when the number of plaques which developed equalled or exceeded the number expected assuming a Poisson distribution of dually infected cells and an efficiency of plaque formation by such cells of 100 per cent.

The results summarized in Table 3 represent at least 4 tests for each mutant pair. All 10 clones of the CR 18 recombinant exhibited the same genetic behavior, therefore only the results with CR 18 clones 6 and 7 are presented as these 2 clones were subsequently used in the hamster studies. The data suggest that the A/AA/6/ 60 cold variant (PI-7) and the 12 ts cold recombinants all share the ts lesion represented by complementation group 1.

Table 3. Production of plaques at restrictive temperature following dual infection with putative single lesion ts mutants, and cold parent or cold recombinants of influenza $A$ virus

Ratio of number of plaques observed at $39^{\circ} \mathrm{C}$ over the number of plaques expected in mixed infection of RMK monolayers with the indicated pairs of viruses ${ }^{2}$

\begin{tabular}{|c|c|c|c|c|c|c|c|c|c|}
\hline \multirow[b]{3}{*}{ Virus } & \multicolumn{9}{|c|}{ Complementation group and prototype viruses ${ }^{b}$} \\
\hline & 1 & 2 & 3 & 4 & 5 & & 6 & & 7 \\
\hline & $\mathrm{R} 1$ & R 8 & $2 \mathrm{C}$ & 304 & 315 & 422 & 454 & 464 & 463 \\
\hline Cold parent $(\mathrm{PI}-7)^{\mathrm{c}}$ & $<.001$ & 50 & 5 & 250 & 2 & 6 & 20 & 20 & 100 \\
\hline $\begin{array}{l}\text { Cold recombinants } \\
\text { CR } 6\end{array}$ & $<.001$ & 10 & 10 & 250 & 10 & 30 & 15 & 10 & 20 \\
\hline CR 12 & $<.001$ & 25 & 5 & 500 & 30 & 100 & 70 & 20 & 500 \\
\hline CR 18-clone 6 & $<.002$ & 6 & 5 & 50 & 50 & 5 & 50 & 30 & 10 \\
\hline CR 18-clone 7 & $<.002$ & 4 & 10 & 150 & 50 & 5 & 50 & 200 & 80 \\
\hline
\end{tabular}

a Based on Poisson distribution, assuming that it is necessary for a cell to receive one plaque forming unit of each virus to produce a plaque at $39^{\circ} \mathrm{C}$. The formula $\left(1-e^{-m A}\right)\left(1-e^{-m B}\right)$ (number of cells) is used where ${ }^{m A}$ and $m B$ are the input multiplicities of the infecting viruses. Values are representative of a minimum of 4 tests between each pair. Each test was carried out on a separate lot of RMK cells and calculations of input virus were based on the titer at $33^{\circ} \mathrm{C}$ of each mutant on that lot of cells

b Reference 25

c Data for the PI-7 virus are also presented in paper I of this series (23) 


\section{Biological Characterization of Cold Adapted Variants in Hamsters}

Previous studies with $t s$ mutants of influenza A virus had demonstrated a correlation between the level of temperature sensitivity and the degree of restriction of replication in the hamster's lungs, i.e. the lower the shut-off temperature the greater the restriction of replication $(14,20,25)$. Since the cold adapted parent PI-7 and its recombinants differed in temperature sensitivity, it was possible that a gradient of restriction of pulmonary viral replication might also be observed.

Hamsters were therefore inoculated intranasally with the PI-7 cold adapted parent, one of the cold recombinants, either CR6 or CR 12, or with the homologous wild type virus. In addition, the ts-[189] (5FU mutant) and its homologous Udorn wild type parent were studied (Tables 1 and 4 ). The ts-[189] virus was chosen since genetic studies had shown that it had the group 1 lesion and $37^{\circ} \mathrm{C}$ shutoff temperature (19).

24 hamsters were infected with each virus and the lungs and nasal turbinates of 6 individual hamsters were harvested daily for 4 days and analyzed for virus

Table 4. Growth of a cold variant, 2 of its cold recombinants, and a ts mulant in the lungs and nasal turbinates of hamsters

\begin{tabular}{|c|c|c|c|c|c|}
\hline \multirow[t]{2}{*}{ Virus } & \multirow[t]{2}{*}{$\begin{array}{l}\text { Shut off } \\
\text { tempera- } \\
\text { ture }\end{array}$} & \multicolumn{2}{|c|}{$\begin{array}{l}\text { Mutant virus, } \\
\text { Maximum yielda }\left(\log _{10}\right. \\
\text { TCID } \\
50 \text { per gram of tissue) }\end{array}$} & \multicolumn{2}{|c|}{$\begin{array}{l}\text { Homologous wild type, } \\
\text { Maximum yield }^{\mathrm{b}} \text { (Log10 } \\
\text { TCID }_{50} \text { per gram of tissue) }\end{array}$} \\
\hline & & Lungs & Turbinates & Lungs & Turbinates \\
\hline PI-7 & 37 & $2.4 \pm 1.2^{d+}$ & $2.2 \pm 0.8^{++}$ & $6.7 \pm 0.4^{*}$ & $3.3 \pm 1.1^{++}$ \\
\hline $\mathrm{CR} 6$ & 37 & $2.1 \pm 1.0^{* *}$ & $3.7 \pm 0.7^{++}$ & $7.2 \pm 0.0^{*}$ & $5.6 \pm 1.2 * *$ \\
\hline CR 12 & 38 & $4.1 \pm 0.8^{* *}$ & $4.2 \pm 0.8^{++}$ & $6.5 \pm 0.2 *$ & $4.1 \pm 0.8^{* *}$ \\
\hline$t s-[189]$ & 37 & $1.6 \pm 0.8^{+}$ & $3.8 \pm 1.3^{++}$ & $7.1 \pm 0.5^{+}$ & $5.6 \pm 0.8^{+}$ \\
\hline \multirow[t]{2}{*}{ Virus } & \multirow[t]{2}{*}{$\begin{array}{l}\text { Shut off } \\
\text { tempera- } \\
\text { ture }\end{array}$} & \multicolumn{2}{|c|}{$\begin{array}{l}\log _{10} \text { reduction } \\
\text { in maximum titer } \\
\text { compared to wild type }\end{array}$} & \multicolumn{2}{|c|}{$\begin{array}{l}\text { Number of isolates } \\
\text { from which } t s^{+} \text {virus } \\
\text { recoveredc }\end{array}$} \\
\hline & & Lungs & Turbinates & Lungs & Turbinates \\
\hline PI-7 & 37 & 4.3 & 1.1 & $0 / 6$ & $0 / 5$ \\
\hline CR 6 & 37 & 5.1 & 1.9 & $0 / 8$ & $0 / 17$ \\
\hline CR 12 & 38 & 2.4 & -0.1 & $0 / 13$ & $2 / 21^{\mathrm{e}}$ \\
\hline$t s-[189]$ & 37 & 5.5 & 1.8 & $0 / 2$ & $1 / 11^{p}$ \\
\hline
\end{tabular}

a Maximum virus yields: $*$ =day $1,+=$ day $2, * *$ virus titers on days 1 and 2 were essentially the same, ++ virus titers on days 2 and 3 were essentially the same

b See Table 1 for wild type parent of each variant

- Isolates from day 1-4. were tested for revertant virus. Although 24 hamsters were inoculated with each virus not all animals were infected; in addition some isolates did not yield sufficient virus for titration

d Standard error

e The ratios of $\mathrm{PFU}$ at $39^{\circ} \mathrm{C} / \mathrm{PFU} 33^{\circ} \mathrm{C}$ were 0.01 and 0.001 respectively

i The ratio of $\mathrm{PFU}$ at $39^{\circ} \mathrm{C} / \mathrm{PFU} 33^{\circ} \mathrm{C}$ was 0.0001 
content. The 3 viruses (P17, CR 6 and $t s$ - [189]) with the lower shutoff temperature, i.e. $37^{\circ} \mathrm{C}$, were more restricted in replication in the lungs than was the CR 12 recombinant which had a $38^{\circ} \mathrm{C}$ shut off temperature. In addition each of these viruses manifested a greater level of restriction in the warmer lower respiratory tract $\left(37^{\circ} \mathrm{C}\right)$ than in the cooler upper respiratory tract $\left(34^{\circ} \mathrm{C}\right)$.

To determine whether reversion to the $t s^{+}$phenotype ocourred during replication in the hamster two assays were used: i) roller tube cultures were inoculated with organ homogenates, incubated at $39^{\circ} \mathrm{C}$ and subsequently tested for hemadsorption. ii) isolates from RMK roller tube cultures incubated at $33^{\circ} \mathrm{C}$ were evaluated for their ability to form plaques at $33^{\circ} \mathrm{C}$ or $39^{\circ}$. Revertant $\left(t s^{+}\right.$) virus was not found in the lungs of any of the animals despite the fact that the isolates obtained from the lungs grew to titers of $10^{3}$ to $10^{7} \mathrm{PFU} / \mathrm{ml}$ when assayed in RMK cells at the permissive temperature. Most isolates were assayed twice on 2 separate lots of RMK monolayers. Isolates from the nasal turbinates of two animals inoculated with the CR 12 virus however, yielded virus whose titer in RMK cells at $39^{\circ} \mathrm{C}$ was 0.1 , or 1.0 per cent of its titer at $33^{\circ} \mathrm{C}$ indicating that revertant virus was present as a minor subpopulation in the isolate. Also one of 11 hamsters infected with $t s[189]$ yielded $t s^{+}$virus with a ratio of PFU at $39^{\circ} \mathrm{C} / \mathrm{PFU}$ at $33^{\circ} \mathrm{C}$ of 0.0001 . The properties of these $t s^{\dagger}$ revertants as well as several isolated in subsequent experiments are discussed below.

In a second study the genetic stability of the CR 12 recombinant was compared with that of the $t s-1[\mathrm{E}]$ and $t s$-(clone 13 ) viruses. The CR 12 recombinant was chosen, since of the 3 cold adapted viruses it grew to the highest titer in the hamster respiratory tract. Ts-1 [E] was selected because it has been well characterized in man (15) and in hamsters and like CR-12 has the group $1 \mathrm{ts}$ lesion and a $38^{\circ} \mathrm{C}$ shut-off temperature $(24)$; ts-(clone 13 ) has the group 1 ts lesion and a $39^{\circ} \mathrm{C}$ shut-off temperature $(20,21)$. Fifteen hamsters were inoculated with one of the ts viruses or with CR 12 , and all animals were sacrificed on day 2 since previous studies indicated that this was the day of maximum virus replication for these viruses. When tested in parallel, the CR 12 recombinant appeared to be more stable genetically than either the $t s-1[\mathrm{E}$ ] or $t s$-[clone 13] virus (Table 5). More than half the animals infected with the latter 2 viruses $(9 / 14$ and $10 / 15$ respectively)

Table 5. Comparison of genetic stability in the hamster lung of cold recombinant CR 12 and two ts mutants (ts-1 [E] and ts-[clone 13])

\begin{tabular}{lllc}
\hline Virus & $\begin{array}{l}\text { Shut off } \\
\text { temperature } \\
\left({ }^{\circ} \mathrm{C}\right)\end{array}$ & $\begin{array}{l}\text { Yield day 2 } \\
\left(\log _{10} \text { TCID }_{50}\right. \\
\text { per gram of tissue) }\end{array}$ & $\begin{array}{l}\text { Number of isolates } \\
\text { from which } t s^{+} \text {virus } \\
\text { recovered }^{\mathrm{a}}\end{array}$ \\
\hline $\mathrm{CR} 12$ & 38 & $2.7 \pm 1.1$ & $1 / 10^{\mathrm{b}}$ \\
$t s-[$ clone 13$]$ & 39 & $5.0 \pm 2.2$ & $10 / 15^{\mathrm{c}}$ \\
$t s-1[\mathrm{E}]$ & 38 & $4.0 \pm 2.1$ & $9 / 14^{\mathrm{d}}$ \\
\hline
\end{tabular}

a Although 15 hamsters were inoculated with each virus, not all animals were infected; in addition some isolates did not yield sufficient virus for titration

b The ratio of $\mathrm{PFU} 39^{\circ} \mathrm{C} / \mathrm{PFU} 33^{\circ} \mathrm{C}$ was 0.001

c The ratio of $\mathrm{PFU} 39^{\circ} \mathrm{C} / \mathrm{PFU} 33^{\circ} \mathrm{C}$ was from 0.0001 to 0.1

a The ratio of $\mathrm{PFU} 39^{\circ} \mathrm{C} / \mathrm{PFU} 33^{\circ} \mathrm{C}$ was from 0.001 to 0.01 
had "revertant" virus in the lung isolates, whereas "revertant" virus was found in the lungs of only one of the 10 hamsters infected with CR 12.

The low level of reversion observed in hamsters infected with the PI-7, CR6 and CR 12 viruses suggested that these viruses might be more stable genetically than $t s$ viruses derived by $5 \mathrm{FU}$ mutagenesis. However, neither the PI-7 or CR 6 viruses replicated to high titer in the hamster's lungs. Previous studies with $t s$ viruses indicated that the level of reversion was related to the level of replication in the hamster's lungs $(18,20,25)$. We therefore initiated a third study using PI-7, CR 18 clone 6, CR 18 clone 7 and their parental wild type strains (Table 1) to infect hamsters. Both clones 6 and 7 had the hemagglutinin and neuraminidase antigens of the Scotland parent, but differed in that clone 6 had a shut-off temperature of $38^{\circ} \mathrm{C}$, while clone 7 shut-off at $37^{\circ} \mathrm{C}$.

As seen in Table 6: i) both CR 18 clones replicated well in the hamster lung; ii) clone 6 , which had the higher shut-off temperature, grew to higher titer than. clone 7 ; iii) the level of replication in the lung and the frequency of reversion to the $t s^{+}$phenotype of these 2 clones was comparable to that of the $t s-1[\mathrm{E}]$ and

Table 6. Growth of a cold variant, PI.7, and two of its cold recombinants in the lungs and nasal turbinates of hamsters

\begin{tabular}{|c|c|c|c|c|c|}
\hline \multirow[t]{2}{*}{ Virus } & \multirow[t]{2}{*}{$\begin{array}{l}\text { Shut off } \\
\text { tempera- } \\
\text { ture }\end{array}$} & \multicolumn{2}{|c|}{$\begin{array}{l}\text { Mutant virus, } \\
\text { maximum yield }\left(\log _{10}\right. \\
\text { TCID } 50 \text { per gram of tissue) }\end{array}$} & \multicolumn{2}{|c|}{$\begin{array}{l}\text { Homologous wild type, } \\
\text { maximum yield (Log } 10 \\
\text { TCID } 50 \text { per gram of tissue }\end{array}$} \\
\hline & & Lungs & Turbinates & Lungs & Turbinates \\
\hline PI-7 & 37 & $2.8 \pm 0.4^{* b}$ & $2.4 \pm 0.4^{* *}$ & $4.9 \pm 0.9^{*}$ & $2.9 \pm 0.7^{* *}$ \\
\hline $\begin{array}{l}\text { CR } 18 \text { - } \\
\text { clone } 6\end{array}$ & 38 & $4.0 \pm 0.8^{+}$ & $4.0 \pm 0.9^{+}$ & $6.7 \pm 1.4^{+}$ & $3.0 \pm 0.5^{*}$ \\
\hline $\begin{array}{l}\text { CR } 18- \\
\text { clone } 7\end{array}$ & 37 & $2.9 \pm 0.3^{+}$ & $4.4 \pm 0.3^{*}$ & $6.7 \pm 1.4^{+}$ & $3.0 \pm 0.5^{*}$ \\
\hline
\end{tabular}

\begin{tabular}{|c|c|c|c|c|c|}
\hline \multirow[t]{2}{*}{ Virus } & \multirow[t]{2}{*}{$\begin{array}{l}\text { Shut off } \\
\text { tempera- } \\
\text { ture }\end{array}$} & \multicolumn{2}{|c|}{$\begin{array}{l}\log _{10} \text { reduction } \\
\text { in maximum titer } \\
\text { compared to wild type }\end{array}$} & \multicolumn{2}{|c|}{$\begin{array}{l}\text { Total number of isolates } \\
\text { from which } t s^{+} \text {virus } \\
\text { recovered }^{c}\end{array}$} \\
\hline & & Lungs & Turbinates & Lungs & Turbinates \\
\hline PI-7 & 37 & 2.1 & 0.5 & $0 / 9$ & $0 / 18$ \\
\hline $\begin{array}{l}\text { CR } 18 \text { - } \\
\text { clone } 6\end{array}$ & 38 & 2.7 & -1.0 & $7 / 17$ & $3 / 28$ \\
\hline $\begin{array}{l}\text { CR } 18- \\
\text { clone } 7\end{array}$ & 37 & 3.8 & -1.4 & $6 / 16$ & $1 / 28$ \\
\hline
\end{tabular}

a Maximum virus yields: * = day $1,+=$ day $2, * *=$ virus titers on days 1 and 2 were essentially the same

See Table 1 for wild type parent of each variant

b Standard error

c Isolates from day 1-4 were tested for $t s^{+}$virus. Although 24 hamsters were inoculated with each virus not all animals were infected; in addition some isolates did not yield sufficient virus for titration. The ratio of $\mathrm{PFU}$ at $39^{\circ} \mathrm{C} / \mathrm{PFU} 33^{\circ} \mathrm{C}$ was between 0.01 and 0.001 
ts-[clone 13] viruses; iv) the ratio of PFU at $39^{\circ} \mathrm{C} / \mathrm{PFU}$ at $33^{\circ} \mathrm{C}$ varied from 0.001 to 0.01 in the various isolates. Further characterization of several of these isolates is discussed below.

\section{Characterization of $\mathrm{ts}^{+}$Virus Isolated From Hamster Organs}

To study $s^{+}$virus isolated (RMK 1$)^{1}$ from animals infected with CR 12 or CR 18 we picked plaques which appeared at $39^{\circ} \mathrm{C}$ when isolates from turbinates or lungs were titrated on RMK monolayers. These plaques (RMK2) were subsequently

Table 7. Characterization of ts ${ }^{+}$virus isolated from the lungs and nasal turbinates of hamsters infected with cold recombinants

\begin{tabular}{|c|c|c|c|c|c|c|}
\hline \multirow[b]{2}{*}{$\begin{array}{l}\text { Plaque } \\
\text { number }\end{array}$} & \multirow[b]{2}{*}{$\begin{array}{l}\text { Infecting } \\
\text { virus }\end{array}$} & \multirow[b]{2}{*}{ Organ ${ }^{b}$} & \multicolumn{2}{|c|}{$\begin{array}{l}\log _{10} \text { reduction } \\
\text { of titer from } \\
\text { that at } 33^{\circ} \mathrm{C}\end{array}$} & \multirow[b]{2}{*}{$\begin{array}{l}\text { Appearance of } \\
\text { plaques on CK } \\
\left(25^{\circ} \mathrm{C}\right)\end{array}$} & \multirow[b]{2}{*}{$\begin{array}{l}\text { Inter- } \\
\text { preta- } \\
\text { tion }\end{array}$} \\
\hline & & & $\begin{array}{l}\text { at } \\
39^{\circ} \mathrm{C} \\
\text { in } \\
\text { (RMK) }\end{array}$ & $\begin{array}{l}\text { at } \\
25^{\circ} \mathrm{C} \\
\text { in } \\
\text { (CK) }\end{array}$ & & \\
\hline $1 a$ & $\mathrm{CR} 12$ & NT & 0.0 & 2.0 & late, minute & INT \\
\hline $1 \mathrm{~b}$ & CR12 & $\mathrm{NT}$ & 0.5 & 0.4 & early, normal & $\mathrm{CA}$ \\
\hline $1 \mathrm{c}$ & CR 12 & NT & 1.0 & 1.6 & late, minute & INT \\
\hline 2 & $C R 12$ & $\mathrm{NT}$ & 0.3 & 1.4 & late, minute & INT \\
\hline 3 & CR 12 & Lung & 0.2 & 1.1 & early, normal & $\mathrm{CA}$ \\
\hline $4 \mathrm{a}$ & CR 18-clone 6 & $\mathrm{NT}$ & 0.9 & 2.0 & late, minute & INT \\
\hline $4 \mathrm{~b}$ & CR 18-clone 6 & $\mathrm{NT}$ & 2.9 & $>4.6$ & none & $\overline{N C A}$ \\
\hline 5 & CR 18-clone 6 & Lung & 3.1 & -0.1 & early, normal & $\mathrm{CA}$ \\
\hline 6 & CR 18 -clone 6 & Lung & 3.0 & 0.7 & early, normal & $\mathrm{CA}$ \\
\hline 7 & CR 18-clone 7 & Lung & 1.6 & 3.6 & late, minute & INT \\
\hline 8 & CR 18 -clone 7 & Lang & 2.2 & 0.4 & early, nomal & $\mathrm{CA}$ \\
\hline 9 & CR 18-clone 7 & Lung & 3.2 & 1.0 & early, normal & $\mathrm{CA}$ \\
\hline 10 & CR 18-clone 7 & Lung & 4.1 & 2.3 & early, normal & $\mathrm{CA}$ \\
\hline \multicolumn{7}{|c|}{ Parental viruses } \\
\hline & CR 12 & & $>6.3$ & 0.1 & early, normal & $C A$ \\
\hline & CR 18 -clone 6 & & $>6.2$ & 0.3 & early, normal & CA \\
\hline & CR 18-clone 7 & & $>7.0$ & 0.7 & early, normal & $\mathrm{CA}$ \\
\hline & $\mathrm{A} / \mathrm{AA} / 9 / 73$ & & 0.0 & $>7.0$ & none & NCA \\
\hline & $\mathrm{A} / \mathrm{Seot} / 840 / 74$ & & 0.0 & $>7.5$ & none & $\mathrm{NOA}$ \\
\hline
\end{tabular}

a Plaques were picked from monolayer cultures inoculated with the isolate derived from individual hamster organs and incubated at $39^{\circ} \mathrm{C}$. In the case where several plaques were picked from a single isolate the designation $a, b$, etc., is used

b NT nasal turbinate

c Cold adapted viruses are selected on the eriteria that they produce plaques on chick kidney cells at $25^{\circ} \mathrm{C}$ and that the plaques start to appear at 3 days after inoculation and increase in size with time; hence the designation early, normal. The plaques described as minute and late do not appear until 5 to 7 days after inoculation and do not increase in size

a See text for discussion. CA cold adapted, NCA not cold adapted, INT intermediate

1 Indicates the number of passages in culture of virus from the lung or turbinate homogenate. 
passaged once in RMK roller tubes $\left(33^{\circ} \mathrm{C}\right)$; egg pools were then prepared using the roller tube virus as inoculum. These egg pools (RMK3, Egg 1) were then characterized for the ts property by titration at $33^{\circ} \mathrm{C}$ and $39^{\circ} \mathrm{C}$ on RMK monolayers and for the ca property by titration at $25^{\circ}$ and $33^{\circ} \mathrm{C}$ on $\mathrm{CK}$ monolayers (Table 7). All 12 isolates studied were $t s^{+}$, however, the ratios of PFU at $39^{\circ} / 33^{\circ} \mathrm{C}$ varied from 0.0001 to 1 . The majority of these ratios differed from that of the initial RMK isolate and suggest that either the initial isolate (RMK 1) was heterogenous or that the population of $\varepsilon^{+}$viruses changed during passage to the RMK3, Egg 1 passage level.

When the $t s^{+}$viruses were studied for their ca property three types of clones were seen (Table 7): i) cold adapted: i. e., the ratio of $\mathrm{PFC} 25^{\circ} / 33^{\circ} \mathrm{C}$ was between 0.1 and 1 ; plaques appeared in $3-5$ days and increased in size with time $(6$ clones) ${ }^{2}$; ii) not cold adapted, i. e., no plaques appeared at $25^{\circ} \mathrm{C}$ (1. clone); iii) intermediate, i.e., the ratio of $\mathrm{PFU} 25^{\circ} / 33^{\circ} \mathrm{C}$ was between 0.1 to 0.01 ; the plaques appeared at $5-7$ days and did not increase in size (5 clones). The ca phenotype did not appear to correlate with the ratio of $\mathrm{PFU} 39^{\circ} / 33^{\circ} \mathrm{C}$. In the 2 cases where more than one $t s^{t}$ clone was derived from the turbinates of a single animal differences in the ratio of PFU $39^{\circ} / 33^{\circ} \mathrm{C}$ and the $c a$ property were noted.

\section{Diseussion}

The Nature of the Genetic Lesion(s) in the A/Ann Arbor/6/60-Cold-Adapted Variants and Recombinants Derived From $I t$

Previous analysis showed that the A/Ann Arbor/6/60 cold variant contained a single conditionally lethal ts lesion which failed to complement with $t s$ mutants of group 1 (23). The present study confirms this finding and demonstrates that in 3 of 4 recombination experiments carried out at $25^{\circ} \mathrm{C}$ the gene carrying the conditionally lethal ts lesion of the A/Ann Arbor/6/60 parent was transferred to other strains of the $\mathrm{H} 3 \mathrm{~N} 2$ subtype (CR6, CR 12, CR 18). The overall degree of temperature-sensitivity of the recombinant viruses varied however, as judged by their shut-off temperature when titrated in RMK cells.

The mechanism(s) responsible for the different level of temperature-sensitivity of the cold adapted recombinants remains unknown. It is possible that the gene(s) that are responsible for the temperature-sensitive phenotype have multiple nucleotide substitutions and that reversion or suppression of these alterations can result in a decrease in the level of temperature-sensitivity. In addition the level of temperature-sensitivity could be modified by the action of non-ts lesions in genes coming from either parent.

RNA mapping studies of recombinants deriving cold-adaptation and conditionally lethal $t s$ properties from $\mathrm{A} / \mathrm{AA} / 6 / 60$ show that these can only be specified by at most three genes: RNA band 3 (coding for one polymerase polypeptide), the nucleoprotein, and the matrix protein genes $(6,6 \mathrm{a}, 12)$. Biochemical analysis of the recombinants is continuing in an attempt to determine which of these three genes

2 Despite a ratio of $\mathrm{PFU} 25^{\circ} / 33^{\circ} \mathrm{C}=0.005$, plaque 10 was classified as $c a$ because of the size and time of appearance of the plaques which were markedly different from those of the intermediate group. 
contains the conditional lethal ts lesion, and how many of these genes are essential for cold adaptation. The finding that $\mathrm{CR} 13$ recombinant is cold-adapted but not $t s$ suggests that $t s$ and cold-adaptation lesions may be on separate genes which segregated during recombination; however several alternative explanations are possible.

\section{Biological Properties of the Cold-Adapted Viruses}

Previous studies with $t s$ mutants of influenza A virus demonstrated that restriction of replication in hamster lung was greatest for the most temperaturesensitive viruses. This suggested that it is the $t s$ property itself which is responsible for the lower growth in the hamsters lungs (temperature $37^{\circ} \mathrm{C}$ ) compared to the upper respiratory tract $\left(34^{\circ} \mathrm{C}\right)(18,20,25)$. Results with cold-adapted viruses described here are consistent with this hypothesis, in that those mutants with the shut-off temperature of $\leq 37^{\circ} \mathrm{C}$ (A/Ann Arbor/6/60 mutant, CR6 and CR 18, clone 7 ) were more restricted in growth in hamster lungs than mutants with a shutoff temperature of $38^{\circ} \mathrm{C}$ (CR 12 and $\mathrm{CR} 18$ clone 6 ).

Our analysis of the reversion to $t s^{+}$phenotype of mutants following replication in hamster lungs provide some support for another previous observation, that $t s^{+}$ revertants are most frequently detected for mutant viruses that replicate to the highest titers in the hamster lungs $(20,25)$. Thus, revertants were not found for the mutant A/Ann Arbor/6/60 parent or its recombinant CR6, both of which replicated poorly in hamster lungs, whereas revertants were consistently found for recombinants CR 12, CR 18 clone 6 and CR18 clone 7 which replicated well in hamster lungs.

Characterization of the $t s^{+}$viruses isolated from hamster lungs infected with CR 12 or CR 18 recombinants showed that reversion of the ts phenotypic property was only rarely accompanied by total loss of the cold-adaptation phenotypic property. This provides an assurance about the potential safety of cold-adapted viruses as live vaccine strains, since it is probable that viruses retaining some coldadaptation properties will still be restricted in their ability to cause disease or to be highly transmissible in man. This potential safety factor must be added to the other observations that; i) $t s^{+}$revertants are found only as a small proportion of the total virus produced in hamster lungs (above), and ii) human volunteers infected with a cold-adapted recombinant derived similarly to those studied here shed very low levels of virus for only a short period of time (12).

The preliminary characterization of $t s^{+}$virus isolated from hamsters also suggests that the $t s$ and $c a$ properties can be dissociated. Further insight into the roles of the $t s$ and $c a$ properties may emerge from studies: i) comparing the replication of $t^{+}$revertants and the $t s$ parent in the hamster lung ii) comparing the replication of recombinants derived from a cross of the A/Ann Arbor/6/60 cold variant and a particular wt strain and selecting for study a set of recombinants having all of the possible combinations of the $c a$ and $t s$ properties.

\section{Acknowledgments}

The expert technical assistance of Mrs. Helen Lester, Mr. Isaac Fishburne, Mrs. Mary Grace Mullinix, and Mr. W. Lee Cline is greatly appreciated. 


\section{References}

1. Beare, A. S., MaAssab, H. F., TyrRelle, D. A. J., Slepushirin, A. N., Hall, T. S.: A comparative study of attenuated influenza viruses. Bull. WHO 44, 593 -598 (1971).

2. Boudreault, A., Lussier, G., Pavilanis, V.: Caracteres biologiques de souches du virus de l'influenza adaptees a $29^{\circ} \mathrm{C}$ et a $41^{\circ} \mathrm{C}$. Canad. J. Microbiol. 14, 867 to 874 (1968).

3. Davenport, F. M., Hennessy, A. V., Minuse, E., Maassab, H. F., Anderson, G. R., Mitchel, J. R., Heffeltingar, J. C., Barret, C. D., JR.: Pilot studies on mono and bivalent live attenuated influenza virus vaccines. In: Proo, Symp. Live Influenza, Vaccine, 105-113. Zagreb: Yugoslav. Acad. Sci. Arts. 1962.

4. Karber, G.: Method Described. In: Lennetre, E. H., Schmidr, N. J. (eds.), Diagnostic Procedures for Viral and Rickettsial Infections, 4th ed, 49-52. New York: American Public Health Assoc., Inc. 1969.

5. Kendal, A. P., Kiley, M. P. : Characterization of influenza neuraminidase: Peptide changes associated with antigenic divergence between early and late $\mathrm{N} 2$ neuraminidases. J. Virol. 12, 1482-1490 (1973).

6. Kendal, A. P., Cox, N. J., Murphy, B. R., Spring, S. B., Maassab, H. F.: Comparative studies of wild-type and "cold-mutant" (temperature sensitive) influenza viruses. II. Genealogy of the matrix (M) and nonstruetural (NS) proteins in recombinant cold-adapted $\mathrm{H} 3 \mathrm{~N} 2$ viruses. J. gen. Virol. (in press).

6a. KrdG, R. M., Udea, M., PAduse, P.: Temperature-sensitive mutants of influenza WSN defective in virus specific RNA synthesis. J. Virol. 16, 790-796 (1975).

7. MAASSAB, H. F. : Adaptation and growth characteristics of influenza virus at $25^{\circ} \mathrm{C}$. Nature (Lond.) 213, 612-614 (1967).

8. MAassab, H. F.: Biologic and immunologic characteristies of cold adapted influenza virus. J. Immunol. 102, $728-732$ (1969).

9. MaAssab, H. F.; Development of variants of influenza virus. In: BarRy, R. D., MaHY, B. W. J. (eds.), The biology of large RNA viruses, 542-566. New York: Academic Press 1970.

10. Maassab, H. F., Francis, T., Jr., Davenport, F. M., Hennessey, A. V., Minuse, E., Anderson, G.: Laboratory and clinical characteristics of attenuated strains of influenza. Bull. WHO 41, 589-594 (1969).

11. MaAssab, H. F., Kendal, A. P., Davennort, F. M.: Hybrid formation of influenza viruses at $25^{\circ}$ C. Proc. Soc. exp. Biol. Med. 139, 768-773 (1972).

12. MaAssab, H. F., Cox, N. J., Murphy, B. R., Kendal, A. P.: Biological, genetic and biochemical characterization of a cold-adapted recombinant $A / V$ ictoria/3/75 virus and its evaluation in volunteers. Developments in Biological Standardization, International Symposium on Live Influenza A Virus Vaceines (in press).

13. Medvedeva, T. E., Aleksandrova, G. I., Smorodintsev, A. A.: Differentiation of temperature variants of influenza A 2 viruses on the basis of plaque formation. J. Virol. 2, 456-460 (1968).

14. Muls, J., Chanock, R. M.: Temperature-sensitive mutants of influenza virus $I$. Behavior in tissue culture and in experimental animals. J. inf. Dis. 123, 145-157 (1971).

15. Murphy, B. R., Chalhub, E. G., Nusinofy, S. P., Kasel, J., Chanock, R. M.: Temperature sensitive mutants of influenza virus III. Further characterization of the ts-1 [E] influenza A recombinant (H 3N 2) virus in man. J. inf. Dis. 128, 479 to $487(1973)$.

16. Murphy, B. R., Hodes, D. S., Nusinofy, S. R., Spring-Stewart, S., Tuerney, E. L., Chanook, R. M.: Temperature-sensitive mutants of influenza virus V. Evaluation in man of an additional ts recombinant virus with a $39^{\circ} \mathrm{C}$ shut-off temperature. J. inf. Dis. 130, 144-149 (1974).

17. Murphy, B. R., Spring, S. B., Richman, D. D., Tufreney, E. L., Kasel, J., Chanock, R. M.: Temperature-sensitive mutants of influenza virus. VII. Transfer of the $t s-1[\mathrm{E}]$ lesions to a wild-type influenza $A$ virus with the $\mathrm{H} 0 \mathrm{~N} 1$ surface antigens. Virology 66, 533--541 (1975). 
18. Murphy, B. R., Spring, S. B., Ruchman, D. D., Chanock, R. M.: Use of temperature sensitive mutants of influenza $A$ as live virus vaccines strains. Evaluation in laboratory animals, adults and children. Postgrad. med. J. 52, 381-388 (1976).

19. Murphy, B. R., Trerney, E. L., Sertng, S. B., Chanock, R. M.: Temperaturesensitive mutants of influenza A virus. XI. Transfer of the $t s$ lesions in the Hong Kong/68-ts-1 [A] virus to the influenza A/Udorn/72 wild type. J. inf. Dis. 134, $577-584(1976)$.

20. Richman, D. D., Murphy, B. R., Spring, S. B., Colminan, M. T., Chanock, R. M.: Temperature sensitive mutants of influenza virus. IX. Genetic and biological characterization of $t s-1$ [E] lesions when transferred to a $1972(\mathrm{H} 3 \mathrm{~N} 2$ ) influenza A virus. Virology 66, $551-565$ (1975).

21. Richuman, D. D., Murphy, B. R., Chanock, R. M., Gwaltatey, J. M., Douglas, R. G., Bhtis, R. F., Bracklow, N. R., Rose, F. B., Parrtio, T. A., Levine, M. M., CAPLAN, E. S.: Temperature sensitive mutants of influenza A virus. XII. Safety, antigenicity, transmissability and efficacy of influenza A/Udorn/72-ts-1 [E] recombinant temperature sensitive viruses in adult volunteers. J. inf. Dis. 134, $585-594(1976)$.

22. Smordintsev, A. A., Alexandrova, G. A., Chalkina, O. M., Selmyanol, A. A.: In: Sanders, M., Lensatete, E. H. (eds.), Applied Virology, The First Annual Symposium on Applied Virology, 142. New York: Olympic Press 1965.

23. Sprinc, S. B., MaAssai, H. F., Kendal, A. P., Murphy, B. R., Chanock, R. M.: Cold-adapted variants of influenza virus A. I. Comparison of the genetic properties of $t s$ mutants and 5 cold-adapted variants of influenza. Virology 77, 337-343 (1977).

24. Sprine, S. B., Nustnoff, S. R., Mulls, J. V., Richman, D. D., Trerney, E. L., Murphy, B. R., Chanock, R. M.: Temperature-sensitive mutants of influenza. VI. Transfer of $t s$ lesions from the Asian subtype of influenza A virus (H2N2) to the Hong Kong subtype (H 3 N 2). Virology 66, 522-532 (1975).

25. Spring, S. B., Nusinofy, S. B., Therney, E. L., Richman, D. D., Murphy, B. R., Chanock, R. M.: Temperature-sensitive mutants of influenza. VIII. Genetic and biological characterization of ts mutants of influenza virus $A(H 3 N 2)$ and their assignment to complementation groups. Virology 66, 542-550 (1975).

26. VAN KTRK, J. E., MuLcS, J. V., CHANock, R. M.: Evaluation of low temperature grown influenza A 2/Hong Kong Virus in volunteers. Proc. Soc. exp. Biol. Med. 136, $34-41$ (1971).

Authors' address: Dr. S. B. SpRIng, NIH, NIAID, Building 7, Room 301, Bethesda, MD 20014, U.S.A.

Received April 12, 1977 